\title{
How Muslims-Christians-Jews Relations in the Qur'an? (Critical Interpretation of Q. al-Baqarah/2:120 Using Ma'nā-cum-Magzā Approach)
}

\author{
Abdul Muiz Amir \\ Institut Agama Islam Negeri (IAIN) Kendari, Indonesia \\ abdulmuiz@iainkendari.ac.id
}

\begin{abstract}
This article seeks to interpret Q. al-Baqarah/2:120 that is consistently referred by textual-literalism groups of Muslims as preserved in classical commentaries books. Their understanding raises hatred towards the Jews and the Christians, which eventually leads to intolerance acts. The question to be answered by this article is how the ma'nā-cum-magzā approach could become an alternative method in understanding the verse, so it promotes an inclusive attitude towards the Jews and the Christians? This qualita-tive study works under the deconstructivism paradigm. The result of the study shows that the classical understanding of Q. 2:120 leads to theologically normative discourse, from which the legitimation of eternal and universal hatred against the Jews and the Christians finds its base. The ma'nā-cum-magzā approach, on the other hand, suggests that the verse should be situated in its specific socio-political context. Therefore, the Jews and the Christians mentioned by the verse refer specifically to the Jews of Medina and the Christians of Najran for their abuse of religion as the source of legitimacy for their political hegemony. The academic contribution of this study is, therefore, to pro-duce an alternative interpretation that distances the verse from the justification for hatred based on religious credentials.
\end{abstract}

Keywords: Ma'nā-cum-magz $\bar{a}$ approach, Muslims-Jews-Christians relations, Q. al-Baqarah/2:120. 


\section{How Muslims-Christians-Jews Relations in the Qur'an? (Critical Interpre- tation of $Q$. al-Baqarah/2:120 Using Ma'nā-cum-Magzā Approach)}

\section{Introduction}

Since the tragedic incident of $9 / 11$, horizontal conflicts between different religious believers have occurred, as has also been the case for Indonesia (Kadir, 2004). One of the grounds for the battles is the polemical tone raised by interpretation of the Qur'an. This could be seen from the interview conducted by Scott Atran to Abu Bakar Ba'ashir. Abu Bakar


which was allegedly involved in terrorist acts of bombing in Indonesia, such as the first and the second Bali bombing that killed hundreds of people. One of the statements in the interviews goes as follows:

Q: So, in principle, Islam is tolerant?

A: Yes. The most tolerant is Islam. Those who lack tolerance are infidels. The Qur'an says infidels force Muslims to convert into their religion. The Qur'an says in al-Baqara 120, 'The Jews and the Christians will not feel relief until you follow their religion'... (Atran, 2005: 8).

This statement from $\mathrm{Ba}^{\text {'ashir }}$ points to the legitimation of hatred that is motivated by his understanding upon Q. 2:120. His statement is furthermore confirmed by a research conducted by Ismail et al., (2018) and Yaakob \& Long, (2015), suggesting that genealogy of religious radicalism is the textual and literalistic approach to the Qur'an, leading to the championing of exclusivist ideology that understands religion very narrowly. Meanwhile, there are, in fact, other verses of the Qur'an that support the inclusive ideology and require tolerant acts in the multi-cultural society, such as Q. 49:13 and Q. 109:1-6.

There have been several studies concerning the Q. 2:120, such as the studies of Hakan Çoruh (2012), Gürkan (2016) and M. Saifuddin 


\begin{abstract}
Abdul Muiz Amir 102
(2018). They studies Q. 2:120 and Q. 5:51 in which he criticizes the exclusivist ideology of Qur'an interpretation using the contextual hermeneutics to uncovers the socio-historical context of the verses. Additionally, Bakar (2016) and Rokhmad (2012) in each of their studies support the thesis that Q. 2:120 is the root of exclusivist ideology. Additionally, Nurhadi et al. (2013) analyze the words milla, dìn, and $\operatorname{shari}^{-} a$, one of which is mentioned in Q. 2:120, claiming that with such a perspective they escape from ta 'ârud adilla so that the verse could be understood under the light of inclusive ideology. Nevertheless, they fail to offer new insight as alternative interpretations. Therefore, the objective of this research is to uncover the historical-original meaning as well as the contemporary significance meaning of the verse in question to further implement the purpose of the verse in the current situation.

This study operates on qualitative data based on the deconstructivism paradigm. The primary sources of the study are works of literature, including tafsìr, grammatical literature of Arabic, hadìs, and history, while the secondary sources include relevant previous studies. After the compilation of the data, content analysis is conducted with the principles of the hermeneutics of ma 'nā-cum-magzāa, and further described and derived as a theoretical finding. This study is imperative to produce a counter-discourse for exclusivist ideology that leads to intolerance acts between different religious believers. This situation should not be kept as it is, because it simplifies the interpretation of the Qur'an and most importantly damages the primary teaching of Islam. Therefore, this study is imperative to produce a counter-discourse for exclusivist ideology that leads to intolerance acts between different religious believers. If an alternative interpretation
\end{abstract}


103 How Muslims-Christians-Jews Relations in the Qur'an? (Critical Interpretation of Q. al-Baqarah/2:120 Using Ma'nā-cum-Magzā Approach)

of Q. 2:120 is not uncovered, the conventional views presented in commentary books will remain shaping Muslims' understanding of the verse. Therefore, it continues to be referred to as the justification for hatred based on religious credentials.

\section{LITERATUR REVIEW}

Critical Interpretation of Q. al-Baqarah/2:120 from Classical Commentaries Books

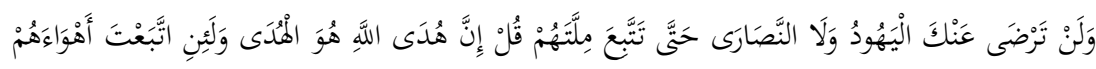

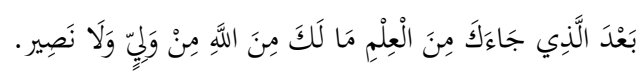

(And never will the Jews or the Christians approve of you until you follow their religion. Say, "Indeed, the guidance of Allah is the [only] guidance." If you were to follow their desires after what has come to you of knowledge, you would have against Allah no protector or helper. [Q. $2: 120])$

Imām aț-Ṭabarī (d. 310/923), in his interpretation of the verse, expresses that:

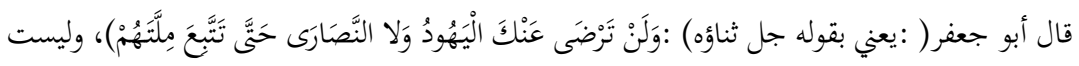

$$
\begin{aligned}
& \text { اليهود، يا محمد، ولا النصارى براضية عنك أبدا. }
\end{aligned}
$$

(Aț-Ṭabarī, 2000).

(Abū Ja'far states: based on the words of God: (wa lan tarḍ̄ 'anka alYahūd wa lā al-Naṣārā hattā tattabi 'a millatahum), and neither the Jews, ya Muhammad, nor the Christians would be contented with you forever...) 


\begin{abstract}
Abdul Muiz Amir 104
Imām aț-Ṭabarī explains that the Q. 2:120 underlines the warning of God to Muhammad, who was persuading the Jews and the Christians to preserve an excellent social life with Muslims after the shift of the Qibla direction. Nevertheless, Allah warned Muhammad to disregard the Jews and the Christians, because they would not be contented with him unless he decided to follow them. In fact, the Jews and the Christians were having a hostile relationship with each other. Therefore, it is highly unlikely for Muhammad to satisfy both communities. In this interpretation, Imām atTabarī seems to consider the term milla as synonymous to ad-dīn (religion).
\end{abstract}

Imām al-Bagāwī (d. 516/1122) presents a piece of interesting information quoted from Ibn 'Abbās:

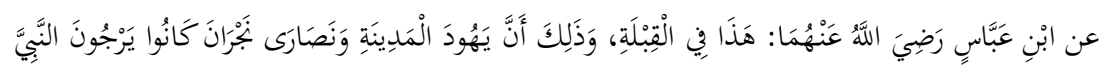

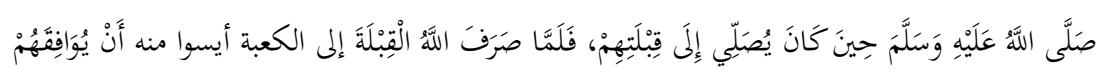

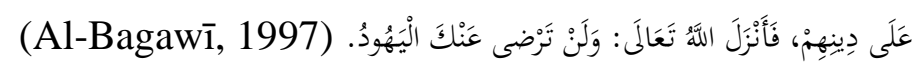

([transmitted] From Ibn 'Abbās raḍiyallāh 'anhuma: this verse is in Qibla. The Jews of Madina and the Christian of Najran wanted the Prophet Muhammad to pray facing their Qibla. When Allah shifted the Qibla direction to $\mathrm{Ka}$ 'ba, they were not pleased with the decision because it deviated from their religion. Therefore Allah reveals, wa-lan tarḍā 'anka al-yahūd...).

Imām al-Bagawī's statement indicates his tendency to understand the verse in the light of its specific context, namely the event of the shift of the Qibla direction. The Qibla of Muslims initially head into Bayt alMaqdīs in Jerusalem, and eventually shifted to Ka'ba in Mecca. The change sparked hostility of the Jews and the Christians against Muslims, 


\section{How Muslims-Christians-Jews Relations in the Qur'an? (Critical Interpre- tation of Q. al-Baqarah/2:120 Using Ma'nā-cum-Magzā Approach)}

for which the Prophet Muhammad attempted at persuading them not to heat the case and keep the social life and emotional relationship between Muslims and both communities. With regards to the word milla, Imām alBagawī understands it as at-tarīqa (path), which means that the Jews and the Christians wanted the Prophet Muhammad to keep facing their Qibla as it had been.

Al-Wāhidī (d. 468/1076) also reveals the same story. He suggests that "Wa-lan tard̄ 'anka al-Yahüd..." is a verse revealed during the event of the shift of the direction of the Qibla, to which the Jews and the Christians wanted to Prophet Muhammad to cancel the shift and face their traditional Qibla, Bayt al-Maqdīs, for prayers. However, Allah asserts that the Prophet should not answer their request and be obedient to the order of Allah “Qul inna hudan Allah huwa al-hudā...”(Al-Waḥid̄̄, 1995).

Both al-Bagawī and al-Wāhidī interpret the verse in a specific context through the occasion of revelation ( $s a b \bar{a} b$ an-nuz $\bar{u} l$ ) transmitted from 'Abdillāh b. 'Abbās. However, neither of them go beyond merely attributing the verse to a particular story of the occasion of revelation; no explanation about the grammatical feature nor historical analysis. As a consequence, we have to deal with a lack of data about who were explicitly the Jews and the Christians in question, were they the whole of the Jews of Madina and the Christians of Najran or specific clan or smaller group within that communities? As a consequence, it is difficult to grasp the concrete communities the verse is dealing with. The above paragraphs reveal problems lying in the interpretation of Q. 2:120 as transmitted in the classical commentaries books. One group of commentary books considers the verse should be applied at face value, whereas the other groups situate it 


\begin{abstract}
Abdul Muiz Amir 106
in a more specific context. Additionally, both kinds of interpretation do not explicitly explain the reason for specifying the significance of the verse as well as the historical motives behind the verse. It is against this problem a critical engagement against the classical views provided by commentary books is needed. Likewise, a comprehensive approach towards the verse

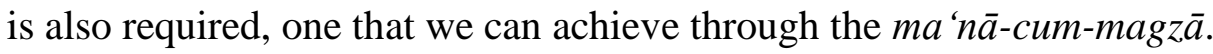

\title{
THEORETICAL FRAMEWORK
}

\section{The Ma'nā-cum-Magzā Approach}

The ma'nā-cum-magzā is an approach developed by Sahiron Syamsuddin. This approach entails three steps of analysis. The first step is grammatical analysis ( $\left.m a^{\prime} n \bar{a}\right)$ based on the principles of interpretation ( 'Ulūm al-Qur'ān), including grammatical analysis, intratextuality of the Qur'an (munāsaba), and intertextual approach, i.e., comparing the Qur'an with other texts such as the hadīs, ancient Arabic poetry, and other texts. In the second step, the historical dimension of the verse is investigated, pacing it in the seventh-century Arab context, both the micro context (asbāb an-nuzūl) and the macro context (the culture of the Arabs on the broader sense). The final step concerns with magzā (significance) or maqșad (substance) of the verse in question. According to Syamsuddin, there are two kinds of significance ( $\operatorname{mag} z \bar{a})$, the phenomenal significance and the ideal significance. The first significance is further broken down into two types: historical significance, in which one should conduct a linguistic analysis upon the text in question along with the micro and macro context analysis, on the one hand, and dynamic significance, in which one should conduct a depth philosophical contemplation as to what the verse should be applied in the current historical situation. The ideal significance 


\section{How Muslims-Christians-Jews Relations in the Qur'an? (Critical Interpre- tation of $Q$. al-Baqarah/2:120 Using Ma'nā-cum-Magzā Approach)}

is the accumulation of the significances of the Qur'an in its specific contexts. This kind of significance is beyond human comprehension because it is the absolute truth that belongs to the author of the Qur'an, namely Allah (Syamsuddin, 2020).

\section{Data Analysis}

Reinterpretation of Q.al-Baqarah/2:120 using the $M a^{6} n \bar{a}$-cum-

\section{Magzā Approach}

\section{Grammatical Analysis $(M a ’ n \bar{a})$}

The word lan and $l \bar{a}$ according to some ulama signify to different meanings. Lan means negation (al-harf an-nafī) upon the act mentioned in the subsequent phrase with a nuance of emphasis (taukid); therefore, it means permanent negation. In other words, the negation using lan is understood to apply endlessly. On the other hand, the majority of ulama considers lan to be constructed by two words, $l \bar{a}$ and $a n$, which refers to temporal negation (Asy-Syafi' '̄, 2013: 110). Likewise, Muhammad Ghalib cites from Ibn Zakariya (w. 941/1004) who suggests that the word lan is used to negate forthcoming act. Besides, Ghalib also quotes al-Aṣfahānī (d. 502/1108) who says that the word $l \bar{a}$ could be used as a negation for an event happening in the past, present, as well as in the future. Furthermore, Ghalib expresses that from the perspective of Balāga, the different word uses for the Jews, lan, and for the Christians, $l \bar{a}$, indicates to different attitudes between the two groups; the hostility shown by the Jews were superior compared to that was shown by the Christians (Ghalib, 2016).

The word 'ank is constructed by two words 'an and $k a$. The word $\mathrm{ka}$ in Arabic is the contraction of the singular personal pronoun for the 


\begin{abstract}
Abdul Muiz Amir 108
second person (damīr mufrad li al-mukhātab, mustatīr taqdīrūh ant). In the context of Q. 2:120, the word refers to the Prophet Muhammad. Here a question arises, whether the word signifies specifically to the Prophet Muhammad alone or Muslims in general? al-Bantanī (d. 1316/1898) states thad the word 'ank refers specifically to the Prophet Muhamad solely, not to Muslims in general, because it uses the singular personal pronoun. It should have related to Muslims in general only if the verse used the plural personal pronoun 'ankum (Al-Bantānī, 1888).

In addition to that, there is a principium in the interpretation of the Qur'an saying that if a verse deals specifically with the Prophet Muhammad for his individual prophethood mission, it does not apply to his followers. This principium seems to fit this verse correctly. That is because a thematic analysis employing intratextual approach (munāsaba) - that is understanding the verse in relation to the previous and subsequent verses - points out that Q. 2:120 is indeed about the personal prophethood mission of Muhammad. Q. 2:119 talks about the specific duty of the Prophet Muhammad as the messenger of God's revelation (basyira wa nażirra) as well as emphasizes the responsibility of the Prophet Muhammad upon humankind. The subsequent verse, Q. 2:121, on the other hand, tells the Prophet Muhammad that the Jews and the Christians are the people that were given Divine's guidance through scriptures so that basically they had understood the mission of the Prophet Muhammad (Al-Bantānī, 1888). As it goes, this thematic context indicates that Q. 2:120 deals with the principle of Muhammad's prophethood mission; therefore, it applies specifically to him instead of to Muslims in general.
\end{abstract}




\section{How Muslims-Christians-Jews Relations in the Qur'an? (Critical Interpre- tation of Q. al-Baqarah/2:120 Using Ma'nā-cum-Magzā Approach)}

The word al-Yahūd, according to al-Farāhī (d. 1348/1930), is etymologically derived from had-yahūd-haudan, which means tāb wa raja 'a (to repent and to come back). However, this meaning is not the basic meaning of the word al-yahīd in the Qur'anic sense, but rather as the common sense of the Arabic speakers. The Qur'anic al-Yahüd is rooted from the word yahuża, which means "ibn rabi' li al-Ya 'qūb in isnā 'asyar ibn ... fașāra ilā ismuh bañ yahūża" (the offsprings of Ya"qub from his twelve sons, who were later called the son of the Jews) (al-Farāhī 2002: 324-325). There are several derivations of al-Yahūd in the Qur'an: $h \bar{a} d u, h \bar{u} d a n$, and yahüdiyan. The word Yahūd is mentioned on eight occasions across seven verses in three surahs (Q. 2:113,120; 5:18,51,64,82; and 9:30). The Qur'anic use of the word is, however, not simply meant as a name of Abrahamic religion. Instead, it refers to communities of people who use religion as a disguise for political and economic interest, who are not hesitant to take whatever it takes even to the degree of distorting (tahrîf) the teachings of their religion (Q. 4:46 and 5:41).

When the Qur'an mentions al-Yahüd, what appears is description about adverse acts of a particular group of the Jews and God's warning against them, a nuance that is absent every time the Qur'an mentions other derivative forms of the word, such as $h \bar{a} d u, h \bar{u} d a n$, or yahüdiyyan. The word $h \bar{a} d u$ is mentioned on ten occasions across ten verses in seven surahs (Q. 2:62; 4:46,160; 5:41,44,69; 6:146; 16:118; 22:17 and; 62:6). This word refers to the Jews community in general; some of them are believers, while others are al-Yahud (Q. 4:46; 5:41). The word hudan, mentioned six times across three surahs, (Q. 2:111,135, 140; 7:65; and 11:50,58) is revealed in the context of dialogue of faith between God and the followers of Ibrahim, 


\begin{abstract}
Abdul Muiz Amir 110
Isma'il, Ishaq, and Ya'qub who were the target of God's encouragement for upgrading their faith. The word Yahudiyan, mentioned only in one occasion in Q. 3:67, reveals the core teaching of those prophets (Haleem \& Elsaid M. Badawi, 2008).

The preceding elaboration shows that the word al-Yahīd in the Qur'an is not identical to the Jews as a religion as is usually the case for the classical commentary books as well as the common sense of general Muslims. Instead, it refers to one part of the group that triggers social problems for their use of religion as a disguise for a particular interest. For that

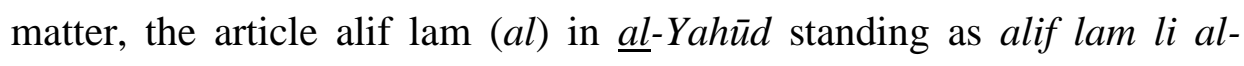
jinsiyya 'ahdiyya, specifies the meaning of the word as the Jews of Medina who had adversary act, namely, making religion as their mask for their political and economic interest. Alif lam li al-jinsiyya al-'ahdiyya is one type of alif lam that specifies the meaning of a word that previously mentioned to signify to a general sense. In this context, the phrase yahüdiyan that means general followers of the Jews, is eventually attributed with alif lam li al-jinsiyya al- 'ahdiyya - becomes al-yahüd - from which the meaning is specified to those who resided in Medina and felt the presence of the Prophet Muhammad as a threat.
\end{abstract}

Let move onto an-Nașārā. According to some linguist, the plural form of the word is Nasran, parallel to nadāma-nadman. (al-Farāhī 2002:322) The word is mentioned through various derivative forms, such as an-Nașārāa (with alif-lam), mentioned nine times across eight verses in four surahs (Q. 2:62,113,120; 5:18,51,69; 9:30; and 22:17), Nasära-(without alif lam), mentioned in five occasions across five verses in two surahs 


\section{How Muslims-Christians-Jews Relations in the Qur'an? (Critical Interpre- tation of Q. al-Baqarah/2:120 Using Ma'nā-cum-Magzā Approach)}

(Q. 2:111,135,140; and 5:14,82), anșārī, mentioned only twice in two different verses of two different surahs (Q.3:52 and 61:14), and anșārallāh or anșārullāh, mentioned only once in Q. 61:14. The word an-Nașārā (with alif lam) is mentioned along with hādu in three times (Q. 2:62; 5:69 and; 22:17), while in the other five occasions is mentioned along with alYahud (Q. 2:113,120; 5:18,51 and; 9:30). It appears that when the word al-Nasara is mentioned along with hadu, the tone of the verse is positive.

On the other hand, every time the word is mentioned alongside al$Y a h \bar{u} d$, the tone of the verse is negative. This means that the word anNaṣarā cannot be understood as having a general meaning, as is the case with $a l-Y a h \bar{u} d$. Instead, some of an-Nașārā are the obedient believers such as $h \bar{a} d u$, while others are like $a l-Y a h \bar{u} d$. This is the reason the Qur'an uses the word lan for al-Yahüd (wa lan tard̄a 'ank al-Yahüd) and la for anNașārā (wa la an-Nașārā) in Q. 2:120. Another opinion suggests that the word lan for al-Yahüd implies that their hostility against the Prophet $\mathrm{Mu}-$ hammad was higher than that of the Christians. That is the reason the word $a n$-Nașārā is, unlike $a l-Y a h \bar{u} d$, only attributed to $l \bar{a}$. However, The word Nașārā (without alif lam) has a different tendency. Every time the word is mentioned along with al-Yahüd, the textual context of the verse is making a comparison between a group of hostile Jews and the friendly Christians. This is the case for Q. 5:82 that pictures the harmonious relation between Muslims and a part of the Christians. Therefore, the hostility of the Jews against the Prophet Muhammad is usually understood to be stronger than that of the Christians. This topic would be further elaborated in the discussion about the micro and macro context of the verse. 


\begin{abstract}
Abdul Muiz Amir 112
2. Historical Analysis (Micro and Macro Context)

Muhammad al-Jauzī (d. 597/1114) reveals three stories of occasions of revelation (asbāb an-nuzūl) of Q. 2:120. The first story is related to the event of the shift of the Qibla direction from Bayt al-Maqdīs in Jerusalem to Ka'ba in Mecca. The second story reveals that the verse was revealed in relation to an invitation of the Jews and the Christians to follow their religion. The final story discloses that the verse was revealed when the Jews and the Christians negotiate with the Prophet Muhammad during the Khaibar war for an armistice. Concerning these three different stories, the majority of the Qur'an commentators agree with the first one, considering it as a widely recognized (masyhūr) account (Al-Jauzī, 2001).

One question emerges: does the meaning of the verse applies to a specific historical context of its occasion of revelation (sabab an-nuzūl), either with regards to its subject or its object, or does it applies as its general meaning? To answer this question, it is imperative to address issues around three principiums in $u s \underline{u} l$ al-tafsìr with regards to sabab an-nuzūl. Two of the principiums are: "Al- 'ibrah bi- 'umūm al-laf̧ lā bi-khuṣuṣ al$s a b a b$ " (a maxim [is referred] for its general sense of the wording, not for the particular case [of its occurence]) and "Al- 'ibrah bi-khuṣuṣ as-sabab là bi- 'umūm al-lafž" (a maxim [is referred] for its specific case [of its occurence], not for the general sense of the wording) (Bakri, 2016). Based on the grammatical analysis as in the preceding, the meaning of Q. 2:120 applies specifically to the Prophet Muhammad, based on the pronoun used, 'anka, which is the singular personal pronoun of the second person (khit $\bar{a} b$ $a l$-wăhid). Likewise, historically, the occasion of the revelation of this particular verse applies specifically to specific communities- the Jews of
\end{abstract}




\section{How Muslims-Christians-Jews Relations in the Qur'an? (Critical Interpre- tation of Q. al-Baqarah/2:120 Using Ma'nā-cum-Magzā Approach)}

Madina and the Christians of Najran - in one specific place and time, as well as one particular momentum, which is the event of the shift of the Qibla direction.

Accordingly, the clause wa lan tarḍ̄ 'anka al-yahūd wa la alnașāra hattā tattab 'a millatahum cannot be understood as its general sense of the wording. For that matter, both of the preceding principiums do not fit this case. That both of the previous principiums are not relevant for this case, the option remains is the third principium, namely " $A l$ - $i b r a b i$ maqāṣidiha" (a maxim [is referred] for its significance/intention). Aḥmad al-Rashūnī explains that this principium could become a new clue for any commentator to uncover the primary meaning of the Qur'an without falling into misunderstanding. However, to have a grasp on the significance of the verse, a textual-literal analysis is not enough; instead, Historical information about issues on the time of the revelation is imperative ( $\mathrm{Ar}$ Raysūnī 1995).

Getje, in his research, discloses that the Jews had inhabited Yasrib a hundred years before the hijra of the Prophet Muhammad to the city, specifically In around year $700 \mathrm{AD}$ after Jerusalem was defeated by Titus. Up until 135 AD since the subjection of Jerusalem, the Jews had migrated to the Arab peninsula (Gätje, 1997). Additionally, Muhammad 'Alī Quṭb (d. 1435/2014) also suggests that before the hijra of the Prophet to Yasrib, further named Madina, the city was ruled by the Jews with three elemental power: religion, economy, and politics (Quṭb, 1985). Having the same argument, al-'Alī (d. 1424/2003) in a more detail explains that the Jews established their political power at that time. Yasrib people lived under the 


\begin{abstract}
Abdul Muiz Amir 114
hegemony of the Jews through their domination in trade, agriculture, education, military, architecture, control over money (economy), and so on. In education, the Jews were recognized for their literacy skills, while at the same time, Arab people of Yasrib were inferior to them, making them hold a derogatory status of ummī (illiterate community). The Jews, therefore, took the role of the educator over Arab people in the city. For that matter, the civilization of the Jews considered superior over the indigenous Arabs of Yasrib and its surroundings which were mostly pagan ('Alī, 1988).

Khalīl 'Abd al-Karīm (d. 1422/2002), who cites from Ibn Khaldūn (d. 808/1406), states that the hegemony of the Jews gave rise to a dogma, saying that the subordinate society should follow the community with power, either in communication (syi'ār), lifestyle, ideology, and religion. Considering that the Jews were superior in many fields and their civilization was deemed to be advanced, the Arabs of Yasrib tried to adopt the Jews' way of thinking and way of life. Karìm, furthermore, emphasizes that the Prophet Muhammad came with the concept of akhlāq (rạ̣matan li al- 'âlamīn) that was proven to have a strong influence on the Arabs of Yasrib. The Jews were not able to provide similar value, giving way to the Prophet Muhammad to mark his threat to the Jews' hegemony. The initial harmonic relation between the Muslims and the Jews in the early period of the Prophet arrival in Medina did not last extensively, ended by the broken of the Medina Charter by some of the Jews. In fact, they decided to ally with the Quraish of Mecca to fight against the Prophet Muhammad and his followers (Al-Karīm, 1997).
\end{abstract}

The depression of the Jews' influence in Yasrib at that time triggered societal problems that led to political conflicts between certain 


\section{How Muslims-Christians-Jews Relations in the Qur'an? (Critical Interpre- tation of $Q$. al-Baqarah/2:120 Using Ma'nā-cum-Magzā Approach)}

groups of the Jews and the Christian with Muslims. Philip K. Hitti (d. 1398/1978), citing from Aḥmad ibn Yahya al-Baladurī (d. 297/892) reveals a story of a tragedy of war of the alliance of Meccan people, Bedouin tribes, Abissinia, and the Jews of Medina, Banū Quraiẓah, and Banū Naḍīr $(a l-a h \dot{z} \bar{a} b)$, fighting against Muslim in Medina. The tragedy was later known as the war of Khandaq. Muslims army won the fight, while the Jews of Banū Quraizah alone suffered from 600 deaths. The rest of them became outcast, and the lands they left out, mostly were date palm plantation, became the possessions of Muslims. In the following year, in $628 \mathrm{AD}$, the Jews of Banū Nadīir that resided in Khaibar (on the northern side of Medina) involved in a fight against Muslims, further known as the war of Khaibar. They lost the battle and were pushed to decide between two options, converting to Islam or paying tribute. After this incident, Muslims took over the political power in the city and saw their influence overcoming that of the Jews which had been established for quite a long time. A massive reformation took place. Friday was introduced as the new holy day as the replacement of Saturday, the sound of $a \dot{z} \bar{a} n$ replaced the trumpet and gong, Ramadān was made the fasting month, and the Qibla direction was shifted from Bayt al-Maqdīs in Jerusalem to Ka'ba in Mecca (Hitti, 1989).

This macro context reveals that the hatred of the Jews and the Christians over Muslims was primarily not about the different of faiths, but rather about the contestation for political hegemony between the status quo in which the Jews were the leaders of the community and the Muslims who were seeing their ascension to a higher power. For the Jews of Medina, the difference of faiths was of the common phenomena. Before the 


\begin{abstract}
Abdul Muiz Amir 116
coming of Islam, the Jews were known to have been living alongside the Arabs of Medina who were mostly the pagan. In fact, it was the Jews who established the Medinan civilization within which process the social dichotomy based on faith was not at stake. That was also the case when Islam first came to Medina. The Jews agreed to join a mutual agreement between different communities in Medina for a harmonic social relation, namely șahịfa of madīna (the Medina Charter) (Haykal 2015).

This historical context indicates that not all Jews were in conflict with the Prophet Muhammad and Muslims, but rather part of them who felt disturbed by the growing influence of Muslims, a situation which led them to great envy. On the other hand, the Christians showed a slightly different attitude; they were more friendly to the Prophet Muhammad compared to the Jews of Medina (Ibn al-Asīî 1997). This was because the Christians had rahib and priests who intensively guided their followers to the moral code rooted from 'Īsā, for which their teaching was considered pure at that time. One of the teachings preserved by the Christians at that time was the value of $z u h \bar{u} d$. Additionally, the Christians did not have the political power in Medina, as did the Jews. Accordingly, there were relatively fewer conflicts between Muslims and Christians in Medina (Shihab 1992). Against this backdrop, it is reasonable that the Qur'an depicts the friendliness and the affection of the Christians, one of which is Q. 57:27. Fazlur Rahman (d. 1408/1998) explains that the Qur'anic verses addressing the Christians should not be understood with a generalization because the verses depicting threat on them were revealed in particular time, place, and social groups, as was also the case for verses that mention God's praise upon them (Rahman 1980).
\end{abstract}




\section{How Muslims-Christians-Jews Relations in the Qur'an? (Critical Interpre- tation of Q. al-Baqarah/2:120 Using Ma'nā-cum-Magzā Approach)}

Based on this historical context, I argue that Q. 2:120 should not be generally understood as legitimating hatred and hostility that are motivated by the difference of faiths. This statement is supported by several stories picturing episodes of the Prophet Muhammad and Muslims' life that live side by side in harmony with communities of other faiths (the Jews, the Christians, and other religions). There are many reports that reveal that the Prophet Muhammad maintained his social interaction (mu'ämala) with non-Muslims, that he attended a treat (walima) of his non-Muslim's fellow in Medina, that he visited those who were sick or suffering hard luck, that he welcomed guests from the Christians of Najran providing them with a long coat stretched on ground as pedestal to show his respect upon them, and so on. Additionally, the Prophet Muhammad did not prohibit his companions to cite reports that later known as isrā'îli$y \bar{a} t$, although he warned them to clarify the validity of those reports (Gürkan, 2016). Likewise, the companions of the Prophet Muhammad preserved the harmonious and tolerant relation with other faiths. 'Umar b. alKhațāāb once judged a legal dispute between 'Alī b. Abī Ṭālib (d. 40/661) and a Jews, in which his decision did not consider the different faith of each party (Hasan, 2005). If the Prophet Muhammad and his companion lived in tolerance and harmony with other religions in Medina, therefore Q. 2:120 should not be understood to legitimate exclusivism for its status as a madaniyya verse.

3. The Significance Meaning (Magzā) of Q. al-Baqarah/2:120

The preceding textual and contextual—both micro and macro context-analysis shows that the historical-phenomenal significance of the verse reveals that the verse is an answer to a specific case of the shift of 


\begin{abstract}
Abdul Muiz Amir 118
the Qibla direction that became a concern of the Jews of Medina and the Christian of Najran. Their interest was a response to a growing social change, where they had been enjoying a privilege as the leaders of the society in Medina whose influence dictate the political and economic development but were pushed to see the rise of the Prophet Muhammad's influence. The shift of the Qibla direction showed that Islam did not affiliate to the Jew's control, let alone that they were deceiving religion for the sake of their political and economic interest. For that matter, with Q. 2:120, Allah convinced the Prophet Muhammad to not easily deceived by their tricks, because they would do whatever it takes to put Muhammad and his followers under their control.

Theological teachings of religion could not be the hatred label only because some of its adherence commit criminal and evil deeds. This is the reason why Douglass Pratt (2010) states that comprehensive historical studies on the social relation between the Jews, the Christians, and Muslims are imperative. The three religions share the same ultimate goal of spirituality that is establishing peace and social order. Studies on interreligious relations through seminars, symposiums, and so on, should not deal with normative theology any longer. Instead, those studies need to address the question of common words and other principles shared between the three religions (Jukko, 2014). Muslims these days are facing the interpretive tradition that presented views contradicting teachings practiced in the early period of Islam. Those traditions come from militant, fanatic, and puritan Islamism. This is the result of disappointment raised by the politics of frustration that is influenced by the illusion of power in the past (Shah, 2007; Tibi, 2012). On the other hand, there are also Muslims who commit
\end{abstract}




\section{How Muslims-Christians-Jews Relations in the Qur'an? (Critical Interpre- tation of Q. al-Baqarah/2:120 Using Ma'nā-cum-Magzā Approach)}

to preserve the Islamic teachings of rahmatan li al- 'álamīn and maintain interreligious tolerance. It is they who are expected to maintain the authentic Islam as it emerged in the Arabian Peninsula in the seventh century. Therefore, the exclusivist ideology in understanding the Qur'an would trigger hostility and hatred against followers of other faiths, while on the other hand, Islam is a religion aiming at creating peace and harmonic life in the world.

\section{Conclusion}

This study reveals that the hermeneutics of ma 'nā-cum-magzā understand the clause Wa-lan tarḍ̄ 'ank al-Yahūd, wa lā an-Naṣārā hattā tattabī'a millatahum..., in Q. 2:120 as a kinaya (metaphor), or in other words, referring to a specific case of the Jews of Madina and the Christian of Najran. In this situation, both communities did not represent a particular religion but rather as limited individuals who took benefit from religious issues to achieve their political interest. Therefore, to understand the clause as justifying religious hatred is misleading. Whereas the clause Wa-la'ini itabba 'ta ahwā' ahum ba 'da al-làī jāa' ak min al- 'ilm..., represent the main message (the magzā) of Q. 2:120. Accordingly, the verse stands as a warning to not prioritize carnal desire through which teachings of religion are manipulated for the politic and economic interest as it will lead to social chaos. For that matter, Q. 2:120 emphasizes whoever of any religious believers, including Islam, conduct such an act is subject to the condemnation of God through His words Mālak minallāh min waliyyin wa lā nașìr... Based on the previous analysis, it is quite apparent that the verse does not provide legitimation for hostility against the Jews and the Christians in its general sense, which is communities of their respective faiths. On the other 


\begin{abstract}
Abdul Muiz Amir 120
hand, this verse warns about the danger that would potentially arise from a group of people who make religion as a mask for their selfish political or economic interest, as what happened to the Jews of Medina and the Christians of Najran in the Prophet Muhammad era. This is the dynamic-phenomenal significance of the verse.
\end{abstract}

\title{
References
}

'Alī, Șālị̣ Aḥmad. (1988). Ad-Dawlah fī 'Ahadi ar-Rasūl. Mansyūrāt alMajma' al-'Ilmi Al-'Irāqī. P. 167.

Asy-Syafi' '̄, Muḥammad al-Khuḍarī. (2013). Hasyiyah al-Khuḍarī 'alā Syarh Ibn 'Aqūl 'alā Maṭn Alfiyah Ibn Mālik. Dār Ihyā' al-Kutub al'Arabiyah. P. 110.

Atran, S. (2005). The Emir: An Interview with Abu Bakar Ba'asyir, Alleged Leader of the Southeast Asian Jemaah Islamiyah Organization. Jamestown Foundation, Spotlight on Terrorism, 3(9), 1-26. https://jeannicod.ccsd.cnrs.fr/ijn_00000631/

Al-Bagawī, Abū Muhammad b. al-Husain b. Mas'ūd. (1997). Ma 'ālim atTanzìl fì Tafsīr al-Qur'ān. Dār Țaybah lī an-Nasyr wa at-Tauzī‘. P. 161.

Bakar, A. (2016). Argumen al- Qur'an tentang Eklusivisme, Inklusivisme, dan Pluralisme. Toleransi: Media Komunikasi Umat Beragama, 8(1), 43-60. https://doi.org/10.24014/trs.v8i1.2470

Bakri, S. (2016). Asbabul Nuzul: Dialog Antara Teks dan Realitas Kesejarahan. At-Tibyan: Jurnal Ilmu Al-Quran Dan Tafsir, 1(1), 118. https://doi.org/10.32505/at-tibyan.v1i1.30

Al-Bantān̄̄, Muḥammad Nawāwī al-Jāwī. (1888). Marāh Labịd li-Kasyaf Ma'nā al-Qur'ān al-Majīd. Al-Maṭba'ah al-'Uśmaniyah. P. 10.

Gätje, H. (1997). The Qur'ān and Its Exegesis. Oxford. Oneworld Publications. PP. 126-129.

Ghalib, M. (2016). Ahl al-Kitāb; Makna dan Cakupannya dalam Al- 
121 How Muslims-Christians-Jews Relations in the Qur'an? (Critical Interpretation of $Q$. al-Baqarah/2:120 Using Ma'nā-cum-Magzā Approach)

Qur'an. Edited By Kaha Anwar. IRCiSoD. P. 10.

Gürkan, S. L. (2016). Jews in the Qur'ān: An Evaluation of the Naming and the Content. Ilahiyat Studies: A Journal on Islamic and Religious Studies, $7(2)$, 163-206. https://doi.org/10.12730/13091719.2016.72.14

Haleem, M. A., \& Elsaid M. Badawi. (2008). Arabic-English: Dictionary of Qur'anic Usage (H. Altenmuller, B. Hrouda, B.A. Levine, K.R. VEenhof, \& C.H.M. Verteegh (eds.); Digital). Brill. P. 1060.

Haykal, Muḥammad Ḥusain. (2015). Hayāt Muḥammad. Dār al-Ma‘ārif. P. 312.

Hitti, Philip. K. (1989). History of The Arabs (Cet. 10). Macmillah Education Ltd. PP. 117-118.

Ibn al-As̀īr, 'Abd Karīm al-Syaibān̄̄ al-Jazarī. (1997). Al-Kāmil fì atTarīkh. Dār al-Kitāb al-'Arabī. Vol. 2, PP. 79-81.

Ismail, A. M., Wan Kamal Mujani, \& Ahmad Aiman Zuhaily A.M. (2018). Methods of Da'wah and Social Networks in Dealing with Liberalism and Extremism. Islämiyyāt, 40(2), 131-139. https://doi.org/10.17576/islamiyyat-2018-4002-05

Al-Jauzi, Jamāluddīn 'Alī b. Muhammad (2001). Zād al-Masīr fì 'Ilmi atTafsìr. Edited By 'Abd ar-Razzāq al-Mahdī. Dār al-Kutub al-'Arabī. P. 107.

Jukko, R. (2014). Do We Worship the Same God? Jews, Christians, and Muslims in Dialogue. Islam and Christian-Muslim Relations, 25(1), 126-127. https://doi.org/10.1080/09596410.2013.840081

Kadir, S. (2004). Mapping Muslim Politics In Southeast Asia after September. The Pacific Review, 17(2), 199-222. https://doi.org/10.1080/0951274042000219824

Al-Karīm, K. 'Abd. (1997). Quraisy min al-Qabīlah Ilā ad-Dawlah alMarkaziyah. Sīna li al-Nasyr. P. 155.

Nurhadi, R., Syamsul Hadi, Thoyib I. M., \& Suhandano. (2013). Dialektika Inklusivisme Dan Eksklusivisme Islam Kajian Semantik Terhadap Tafsir Al-Quran Tentang Hubungan Antaragama. Jurnal 


\section{Abdul Muiz Amir 122}

Kawistara, 1(21), 58-67. https://doi.org/10.22146/kawistara.3961

Pratt, D. (2010). Muslim-Jewish relations: Some Islamic paradigms. Islam and Christian-Muslim Relations, 21(1), 11-21. https://doi.org/10.1080/09596410903481820

Quṭb, M. 'Alī. (1985). Ma 'ārik an-Nabì ma 'a al-Yahūd wa al-Isrā'iliyah al-'Arabiyah al-Muwādah. Maktabah Madbulī. P. 18.

Rahman, F. (1980). Major Themes of the Qur'an. Bibliotheca Islamica Publisher. P. 24.

Ar-Raysūnī, Aḥmad. (1995). Naẓariyah al-Maqāṣīd 'Inda al-Imām asySyātịīi. Al-Ma‘had al-‘'Ālamī li al-Fikrī al-Islāmī. P. 360.

Rokhmad, A. (2012). Radikalisme Islam dan Upaya Deradikalisasi Paham Radikal. Walisongo, 20(1), 79-114. https://doi.org/10.21580/ws.20.1.185

Shah, M. A. (2007). Book Review of Islamic Humanism. Journal of Qur'anic Studies, 8(2), 139-142. https://doi.org/10.3366/jqs.2006.8.2.13

Shihab, M. Q. (1992). Membumikan Al-Quran: Fungsi dan Peran Wahyu dalam Kehidupan Masyarakat. Mizan. P. 362.

Syamsuddin, S. (2020). Metode Penafsiran dengan Pendekatan Ma'nācum-Magzā. In S. Syamsuddin (Ed.), Pendekatan Ma'nā-cum-Magzā atas Al-Qur'an dan Hadis: Menjawab Problematika Sosial Keagamaan di Era Kontemporer (pp. 1-18). Ladang Kata \& AIAT Indonesia.

Aṭ-Ṭabarī, Muhammad b. Ja'far. (2000). Jāmī‘ al-Bayān fì Ta’wīl Āyi alQur'ān. Mu'assasah ar-Risalāh. Vol. 1, P. 562.

Tibi, B. (2012). Islamic Humanism vs. Islamism: Cross-civilizational Bridging. Soundings: An Interdisciplinary Journal, 95(3), 230-254. https://doi.org/10.5325/soundings.95.3.0230

Al-Wahịī̄, Abū al-Ḥasan 'Alī b. Aḥmad. (1995). Al-Wajīz fī Tafsīr alKitāb al-'Azīz. Dār al-Qalam. P. 192. 
123 How Muslims-Christians-Jews Relations in the Qur'an? (Critical Interpretation of Q. al-Baqarah/2:120 Using Ma'nā-cum-Magzā Approach)

Yaakob, Z., \& Long, A. S. (2015). Terorisme Sebagai Cabaran Ideologi Muslim Masa Kini: Satu Analisis Dari Perspektif Falsafah,. International Journal of Islamic Thought, 7(1), 2232-1314. https://doi.org/0.24035/ijit.7.2015.006 